\title{
THE CONTRIBUTION OF FDI AND FINANCIAL DEVELOPMENT ON ECONOMIC GROWTH IN SRI LANKA
}

\author{
S. Maheswaranathan ${ }^{1}{ }^{\square}$, K. M. N. Jeewanthi ${ }^{2}$ \\ ${ }^{1}$ Senior Lecturer in Economics, Faculty of Commerce and Management, Eastern University, Sri \\ Lanka \\ 2 Temporary Assistant Lecturer in Economics, Faculty of Commerce and Management, Eastern \\ University, Sri Lanka
}

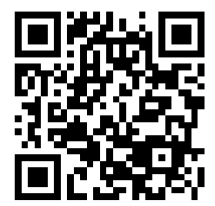

DOI: https://doi.org/10.29121/ijetmr.v8.i1.2021.838

Article Citation: S.

Maheswaranathan, and K. M. N. Jeewanthi. (2021). THE

CONTRIBUTION OF FDI AND

FINANCIAL DEVELOPMENT ON

ECONOMIC GROWTH IN SRI LANKA.

International Journal of Engineering

Technologies and Management

Research, 8(1), 25-34.

https://doi.org/10.29121/ijetmr.v8

i1.2021.838

Published Date: 31 January 2021

Keywords:

Economic Growth

ARDL

Foreign Direct Investment

Financial Development

\section{ABSTRACT}

The present study investigates the relationship between financial development, Foreign direct investment and economic growth in Sri Lanka for the period 1980 to 2019 by applying the Augmented Dickey-Fuller Unit root test along with the ARDL approach in process of achieving the desired objective. The outcome of this study shows that except GDP and FDI all other variables such as Capital investment as a percent of GDP (CI), Bank credit to the private sector as a percent of GDP (BCP), net foreign direct investment inflows in \% of GDP (FDI) are stationary at first difference. The findings reveal that net foreign direct investment inflows are a positive relationship with economic growth in the long run. It means a one percent increase in net foreign direct investment inflows increases the GDP by 0.826439 percent. At the same time, a one percent increase in bank credit to the private sector decreases the GDP by 0.864320 percent. Moreover, in the short run FDI, CI and BCP have a positive and significant impact on GDP. Diagnostic tests such as normality test, heteroskedasticity and serial autocorrelation are employed to validate parameter estimation outcomes. Further, the stability of the variables confirms by the CUSUM test. The country should propose Strategies to boost the growth of efficient domestic financial institutions and encourage policy to attract greater FDI inflows that meet the needs of the knowledge-based economy.

\section{INTRODUCTION}

Financial development and Foreign Direct Investment (FDI) are well known as very much important aspects of the economic growth of a country. Investors and other industries are utilizing FDI as their investments for enlarging their business activities not only in developing countries but also in developed countries. Especially, in developing countries, FDI is a very important economic indicator to proceeding economic growth continuously. Sri Lanka invites FDI because, it accomplishes a major role to upgrade economic growth and as a result of that, it can be seen an improvement of the investment and the living standard of the population. And Sri Lanka has launched numerous policies to attract foreign direct investments to the country since its open economic policy. Alfaro et al. (2004) recommend that through the creation of the backward linkage local financial market allowing FDI to inspire the economic growth of the country. Local financial markets and FDI harmonizing principally attract the development of technological diffusion, and this in turn promotes the economic growth of the nation.

(C) 2021 The Author(s). This is an open access article distributed under the terms of the Creative Commons Attribution License, which permits unrestricted use, distribution, and reproduction in any medium, provided the original author and source are credited. 
Several researchers and scholars, applying FDI and economic growth in their research and identified, FDI generates positive externalities for technology transfer and progress of economic growth (Chee-Keong Choong \& Kian-Ping Lim, 2009). FDI perform a major role in domestic investments in host countries (Belloumi 2002). And FDI is clamping to encourage for creating new jobs, develop technology transfer and progress whole economic growth in host countries.

The well-established financial systems persuade innovations and real growth with effective investment and it reinforces to decrease informational resistance and develop resource allocation effectively. Endogenous growth theories assume that saving is directly influenced by both the equilibrium level of income and the growth rate of the economy. Further, the role of financial development to improve economic growth by extending its services to the public Asghar (2014). Levine (1997) found that managing investments, trading, pooling of savings and utilization and trading goods and services can be improved by the financial development. At the same time $\mathrm{N}$ Asghar and $\mathrm{Z}$ Hussain (2014) found the role of financial development leads to economic growth.

The relationship between the development of the financial sector and economic growth is investigated by several researchers and concluded financial development always stimulates the economic growth of a country (Athambawa and Tohru (2014); Sghaier and Zouheir (2013); Chien L C and C Ping Chang (2009); Hermes and Lensink (2003); Alfaro et al. (2004) and Choong et al. (2004); Omran and Bolbol (2003); Abdalla et al. (2018); Nguyen and Guyen (2017). It is found that the interaction between FDI and financial development exerts a significant effect on the growth performance of Malaysia (Chee-Keong Choong and Kian-Ping Lim 2009).

Eggoh C. Jude (2010) discovered that non-linearity between finance and growth are not quietly solidified. Further Aghion (2005) detailed in his empirical evidence about multiple equilibriums between financial development and economic growth by using convergence clubs. And Deidda and Fattouh (2008) extend this as speculating, there is a connection between the banking sector and financial markets related to economic growth. They indicate the influence of the banking sector on the growth is weak for upward developed financial markets. At the same time, Deidda and Fattouh (2002) have found that there is a nonlinear relationship between finance and growth by using income level as a transition variable. They identified finance development as significant at the highincome level countries only (Eggoh $C$ and Jude 2010). The researchers found a variety of mixing answers for the question. Therefore, the present study tries to investigate whether FDI and financial development may cause economic growth in Sri Lanka during the period 1990 to 2019.

The rest of the study has been arranged as; the second section as the literature review and the third section highlights the methodology of this study and the last section as the conclusion of the study.

\section{LITERATURE REVIEW}

There is a large amount of literature on the impact of foreign direct investment, financial development on economic growth. Using quarterly data from 1996 to 2011 Athambawa and Tohru (2014) studied the relationship between financial development, foreign direct investment and economic growth in Sri Lanka by applying the Johansen cointegration procedure and vector error correction model. They found that there is a long-term positive relationship between financial development and economic growth, and also established a bidirectional causality exists between financial development and economic growth. Further, they illustrated that economic growth and financial development will induce foreign direct investment, but no strong evidence found that foreign direct investment will promote economic development.

Chien C L and C Ping Chang (2009) applying modified panel cointegration and panel error correction model for 37 countries by employing annual time series data from 1970 - 2002, and found substantial solid directions of causality between financial development, FDI and economic growth in the long run. Further, they confirmed the financial development has a larger impact on economic growth compare with FDI. Also, they concluded global outcomes will increases when potential advances associated with FDI attached to financial development. At the same time, Sghaier, Imen and Zouheir (2013) examined the causal relationship between foreign direct investment (FDI), financial development and economic growth in four North African countries (Tunisia, Morocco, Algeria, and Egypt) during the period 1980-2011 and explored that rid of the traditional cross-sectional analysis, foreign direct investment inflows can promote the economic growth of the host country. Applying Generalized Moment (GMM) 
S. Maheswaranathan, and K. M. N. Jeewanthi.

panel data analysis they found a strong positive correlation between foreign direct investment and economic growth. Further, they suggested that the development of the domestic financial system is an important prerequisite for foreign direct investment to have a positive impact on economic growth.

With the emergence of the endogenous growth theory, the contribution of financial markets to growth has received considerable attention. Hermes and Lensink (2003) seem to have popularized the notion that the maturity of the financial sector of the host country is a key prerequisite for the positive impact of foreign direct investment on economic growth. They believe that resources are more effectively distributed within a vibrant financial system, which is a sense that can enhance the absorptive capacity of foreign direct investment recipient countries. In other words, Hermes and Lensink (2003) conducted an empirical study to study the role of the development of the financial system in enhancing the positive relationship between FDI and economic growth. The empirical research presented in this article strongly suggests that this is indeed the case. Among the 67 countries in the data set, 37 countries have fully developed financial systems to enable foreign direct investment to make a positive contribution to economic growth. Most of these countries are located in Latin America and Asia. Almost all other countries in the data set are in sub-Saharan Africa. The financial systems of these countries are very weak, so foreign direct investment has no positive effect on economic growth. Alfaro et al. (2004) and Choong et al. (2004) also came to a similar conclusion that the development of a financial structure lacking a market and related institutions will limit the economy's readiness to obtain benefits from potential FDI spillovers. The same sources indicate that financial development has enhanced the economy's ability to profit from foreign direct investment in three main ways. ${ }^{1}$ Therefore, the complexity of the domestic financial system may play a key role in the host country's ability to absorb foreign direct investment. Then, finance explains economic growth through interaction with foreign direct investment.

Empirical evidence of Omran and Bolbol (2003) shows that the financial system is mainly based on banks and foreign direct investment has not an independent effect on growth, which means foreign direct investment interacts with the minimum level of financial development. Empirical evidence is provided by many studies of FDI, financial development and economic growth by numerous researchers moreover. Abdalla et al. (2018) using annual data from 1970 to 2014, studied the impact of financial development and foreign direct investment on Sudan's economic growth. They have applied unit root and cointegration tests with or without considering the potential structural disruption of the data. FM-OLS and D-OLS estimators are used to obtain estimates with small deviations from longterm models. Also, the marginal effect is calculated to explain the indirect relationship between financial development and foreign direct investment on economic growth. The evidence provided by the cointegration test shows that even if structural fractures are taken into account, there are still long-term relationships between variables. The results show that financial development and foreign direct investment have positive significance in explaining Sudan's economic growth. However, they found that financial development is more beneficial to growth than foreign direct investment and results show that foreign direct investment has brought better economic performance through financial development. And also, they suggest that the development of the financial sector is one of the prerequisites for the country to benefit from foreign direct investment inflows. Further, they mention that more foreign direct investment inflows have increased the size and efficiency of the financial sector and have a positive impact on the Sudanese economy. Nguyen and Guyen (2010) studied the role of domestic financial development in enhancing the positive impact of FDI on the economic growth of Asian developing countries. The study also determined the threshold level of financial development in which foreign direct investment began to have a positive impact on economic growth. The empirical analysis uses balanced panel data from 24 Asian developing countries from 1995 to 2009 . The main findings of this study are very useful for the governments of Asian developing countries in formulating relevant policies to effectively utilize the benefits of foreign direct investment and attract more foreign direct investment. Furthermore, they suggest the development of the domestic financial system is a key condition for the effective use of foreign direct investment income for Asian developing countries.

The relationship between financial development, foreign direct investment and economic growth is investigated by many researchers in many developed and developing countries around the globe. The findings indicate a strong

\footnotetext{
${ }^{3}$ First, due to the expanded credit supply, host country entrepreneurs have limited opportunities to use domestic funds to purchase new machines, adopt the latest technology and attract skilled labor. Second, the development of the domestic financial sector has eased the credit constraints faced by foreign companies, thereby helping to extend innovative activities to the domestic economy. Finally, the existence of an effective financial system promotes the establishment of reverse linkages between foreign direct investment and other economies, especially suppliers of domestic production inputs.

International Journal of Engineering Technologies and Management Research 
positive relationship between FDI, financial development and economic growth in developing countries compare with developed countries. According to the above discussion, countries should reform their domestic financial systems before trying to attract foreign direct investment to develop their economic growth. In the Sri Lankan context, these studies specify a combination of the significant relationship between FDI and economic growth. Some researchers found an insignificant relationship between FDI and economic growth. But, they realized, when put on quasi money $(\mathrm{QM})$ as a proxy for financial development, Financial development and foreign direct investment lead to economic growth.

\section{METHODOLOGY}

It is preferred to study the influence the Financial Development and FDI on economic growth in the Sri Lankan economy between 1990 to 2019 . The following empirical analysis is identified for this study.

$\operatorname{lngdp} t=C 0+C 1 \operatorname{lnfdi} t+C 2 \ln b c p t+C 3 \operatorname{lng} c i+\varepsilon t$

Where

lngdp is GDP growth (\%) (GDP)

lnfdi is Net inflows of FDI \% of GDP (FDI)

lnbcp is bank credit to the private sector as \% of GDP (BCP)

lnci is Capital investment as \% of GDP (CI)

$\varepsilon t$ is the error term

Where, $C 0, C 1, C 2$ and $C 3$ are the parameters to be estimated.

\subsection{COINTEGRATION ANALYSIS (ARDL)}

$1+\varepsilon \mathrm{t}$

$\operatorname{lngdp} t=C 0+C 1(\operatorname{lnfdi}) t-1+C 2(\operatorname{lnbcp}) t-1+C 3(\operatorname{lnci}) t-1++\sum_{t=1}^{n} C 4 \Delta \operatorname{lnfdi} t-1+1+\sum_{t=1}^{n} C 5 \Delta \operatorname{lnbcp} t-1+\sum_{t=1}^{n} C 6 \Delta \ln c \mathrm{i}-$

\subsection{ERROR CORRECTION MODEL (ECM)}

To examine the short-run subtleties and the stability of the parameters of the long-run this study considered the following equation (3) of the error correction model.

$\operatorname{lngdp} t=C 0+\sum_{t=1}^{n} C 1 \Delta \operatorname{lnfdit}-1+\sum_{t=1}^{n} C 2 \Delta \operatorname{lnbcpt}-1+\sum_{t=1}^{n} C 3 \Delta \ln c i t-1+\lambda E C T \mathrm{t}-1+\varepsilon \mathrm{t}$

The study deliberates four variables, such as GDP growth (percent) a proxy of economic growth (GDP), net foreign direct investment inflows in the percentage of GDP, bank credit to the Private sector (\% of GDP) (BCP) and Capital investment as \% of GDP (ci). The sequence of variables (GDP, FDI and BCP) under consideration are stated in $\log$ form.

3.1: List of Variables, Descriptions and Sources

\begin{tabular}{|c|c|c|c|}
\hline Variables & Proxy & Descriptions & Sources \\
\hline GDP & GDP & Percent of GDP & World Bank (2020) \\
\hline FDI & Net inflows of Foreign Direct Investment \% of GDP & Percent of GDP & World Bank (2020) \\
\hline BCP & Bank Credit to the Private Sector & Percent of GDP & World Bank (2020) \\
\hline CI & Capital Investment & Percent of GDP & World Bank (2020) \\
\hline
\end{tabular}

Note: GE= Economic Growth; FDI=Foreign Direct Investment; FD= Financial Development

The analysis makes GDP that is measured in percent of GDP as a proxy for Economic Growth. The net inflow of foreign direct investment is used as a measure in percent of GDP as the proxy for FDI. And gained bank credit to the private sector and capital investment that is measured in percent of GDP as proxies for financial development. The present paper, employed time-series data extract from the period of 1990 to 2019 
S. Maheswaranathan, and K. M. N. Jeewanthi.

\section{DATA PRESENTATION AND DISCUSSION}

\subsection{DISTRICPTIVE STATISTICS}

The following table 4.1 portrayed descriptive statistics of the variables comprised in this present study. The values of mean, standard deviation, maximum, minimum, Skewness, Kurtosis, Jarque-Bera and Probability are reported by the table.

Table 4.1: Descriptive Statistics of the variables

\begin{tabular}{|c|c|c|c|c|}
\hline & LNGDP & LNFDI & LNCI & LNBCP \\
\hline Mean & 1.520866 & 0.011873 & 3.288974 & 3.243695 \\
\hline Median & 1.665754 & 0.095310 & 3.293234 & 3.377586 \\
\hline Maximum & 2.498152 & 1.029619 & 3.665099 & 3.909420 \\
\hline Minimum & 0.000000 & -1.203973 & 3.078233 & 2.174752 \\
\hline Std. Dev. & 0.636263 & 0.488025 & 0.140337 & 0.436812 \\
\hline Skewness & -0.946381 & -0.572065 & 0.508551 & -0.856215 \\
\hline Kurtosis & 3.411482 & 3.007436 & 2.700412 & 3.388719 \\
\hline Jarque-Bera & 6.253105 & 2.181818 & 1.873749 & 5.139200 \\
\hline Probability & 0.043869 & 0.335911 & 0.391851 & 0.076566 \\
\hline Observations & \multicolumn{4}{|c}{40} \\
\hline
\end{tabular}

\subsection{UNIT ROOT TEST}

The present study investigates the relationship between financial development, foreign direct investment and economic growth in Sri Lanka by employing annual time series from 1980 to 2019, with 39 observations of each variable. The selected variables are extracted from the World Bank Development Indicators. Using econometrics analysis, the findings are derived.

Applying Eviews 10, this empirical study has followed the Augmented Dickey-Fuller Unit root test to investigate the stationary of the variables. Following the unit root test, the study continues with the ARDL model, ECM model and diagnostic tests such as the Correlation test, Normality test, hedtrodastisity test and CUSUM test to examine the stability of the variables. The following Table 4.2 and figure describes the results of the Augmented Dickey-Fuller Unit root test.

Table 4.2: Augmented Dickey-Fuller Unit Root Test

\begin{tabular}{|c|c|c|c|c|c|}
\hline \multirow{2}{*}{ Variables } & \multicolumn{4}{|c|}{ Augmented Dickey-Fuller } & \\
\cline { 2 - 6 } & t-Statistic & & t-Statistic & 1 1st Difference & \\
& & Level & & & Suggestion \\
\hline LNGDP & -5.922797 & $0.0000^{* * *}$ & - & - & I $(0)$ \\
\hline LNFDI & -3.950116 & $0.0042^{* * *}$ & - & - & I (0) \\
\hline LNCI & -2.583936 & 0.1048 & -6.955311 & $0.0000^{* * *}$ & I (1) \\
\hline LNBCP & -1.414034 & 0.5656 & -5.756852 & $0.0000^{* * *}$ & I (1) \\
\hline
\end{tabular}


The Contribution of FDI And Financial Development on Economic Growth in Sri Lanka
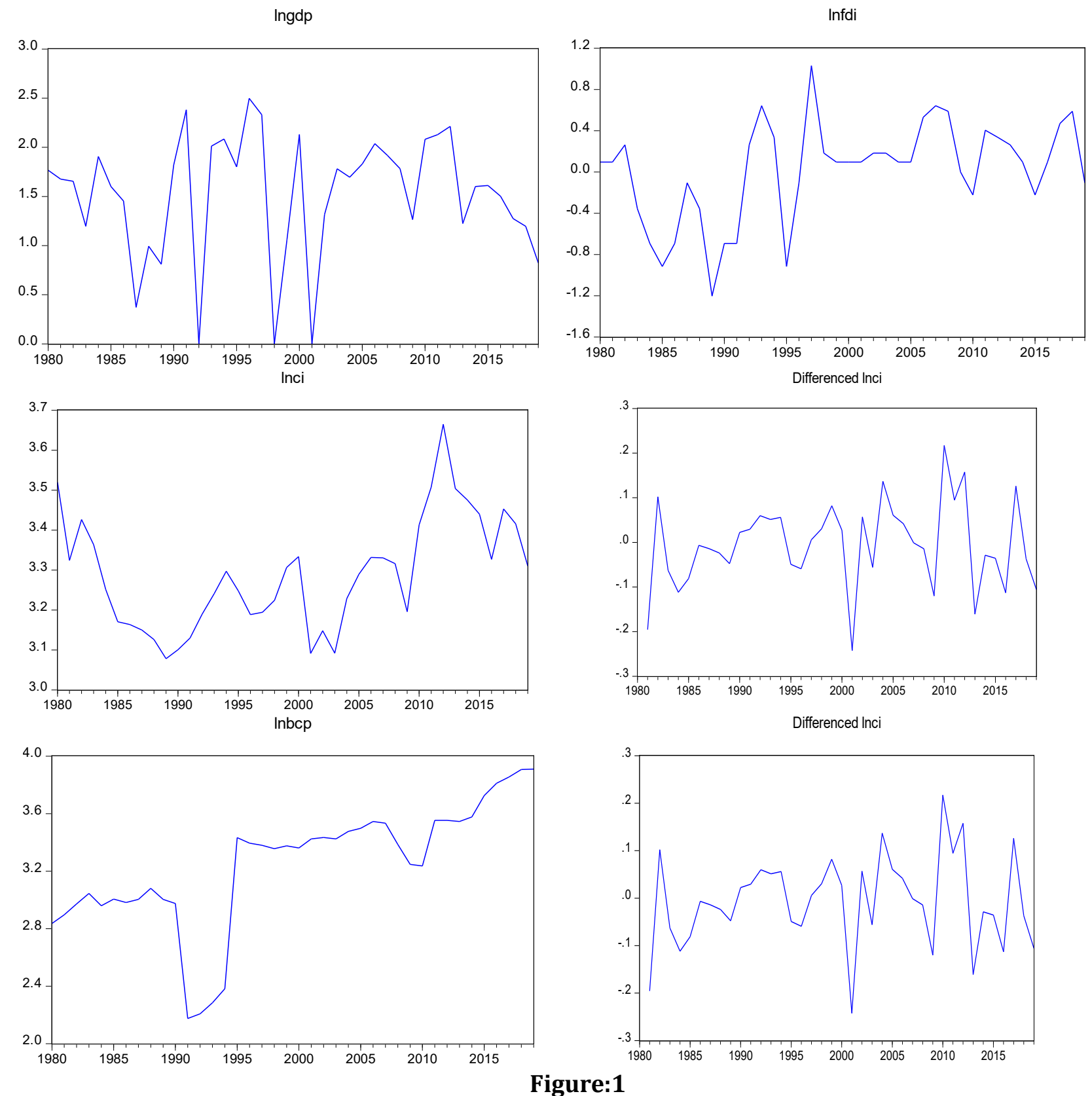

Regarding the above Table 4.2 ADF unit root test the outcome confirms that GDP growth (\%) GDP and Net foreign direct investment inflows in \% of GDP (FDI) are stationary in level (I(0)) and other variables such as Capital investment as a percent of GDP (CI) and Bank credit to the private sector as percent of GDP (BCP) are not in stationary at level but stationary in first difference. Therefore, it is concluded to fix the ARDL bound testing method developed by Pesaran et al. (2001) to investigate the cointegration relationship between the variables. The following Table 4.3 describes the selection of the lag length.

Table 4.3: Lag Length Selection

\begin{tabular}{|c|c|c|c|c|c|c|}
\hline Lag & LogL & LR & FPE & AIC & SC & HQ \\
\hline 0 & -54.26095 & NA & 0.000274 & 3.149240 & 3.323394 & 3.210638 \\
\hline 1 & -5.581109 & 84.20296 & $4.72 \mathrm{e}-05$ & 1.382763 & $2.253529^{*}$ & 1.689749 \\
\hline 2 & 10.05040 & 23.65851 & $4.97 \mathrm{e}-05$ & 1.402681 & 2.970060 & 1.955256 \\
\hline 3 & 37.02760 & $34.99744^{*}$ & $2.99 \mathrm{e}-05^{*}$ & $0.809319^{*}$ & 3.073312 & $1.607482^{*}$ \\
\hline
\end{tabular}


S. Maheswaranathan, and K. M. N. Jeewanthi.

The above table 4.3 indicates that only SC suggests the lag length of 1 but another criterion such as LR PRC, AIC and HQ suggest the lag length of 3 . Therefore, this study considers the lag length of 3.

\subsection{COINTERARATION TEST}

The estimated coefficient of variables for the long run and short run of the ARDL model is illustrated in table 4.4 to validate the existence of the null hypothesis applied the bound test for the presence of the long run relationship. The following table 4.4 indicates the F statistic value which is 14.98509 is greater than the upper value of I(1) at a five percent level and supports to reject the null hypothesis and confirmed the existence of the cointegration relationship between the variables.

Table 4.4: ARDL Bound Test

\begin{tabular}{|c|c|c|}
\hline ARDL Bound Te & \multicolumn{2}{|c|}{ Restricted constant and no Trend } \\
\hline Estimated Equation & \multicolumn{2}{|c|}{$\mathrm{LNGDP}=\mathrm{f}(\boldsymbol{L N F D I}, \boldsymbol{L N C I}, \boldsymbol{L N B C P})$} \\
\hline \multicolumn{2}{|c|}{ Optimal Lag Lenth } & $1,3,1,3)$ \\
\hline \multicolumn{2}{|c|}{ F-statistic } & $14.98509^{* * *}$ \\
\hline Significant Level & Lower bounds I (0) & Upper bounds I (1) \\
\hline $1 \%$ & 4.3 & 5.5 \\
\hline $5 \%$ & 3.1 & 4.0 \\
\hline $10 \%$ & 2.6 & 3.5 \\
\hline
\end{tabular}

The following table 4.5 describes the long run output of the ARDL model. According to the table, Net Flows of Foreign Direct Investment has a positive and significant impact on GDP at one percent of significance level and the elasticity coefficient value of 0.826439 indicates that a one percent increase in FDI increases the GDP by 0.826439. These findings are stayed with Nguyen and Guyen (2010) for Asian countries, Abdalla et al. (2018) for Sudan that FDI has a positive and strong correlation with the GDP of the country. But Athambawa and Tohru (2014) found a negative relationship or less motivation of FDI to promote the GDP in Sri Lanka.

Bank credit to the private sector as a percent of GDP (BCP) has a negative and significant influence on the GDP of the country from 1980 through 2019 at a one percent level. The coefficient value illustrated at BCP is associated with 0.864320 indicate that a one percent increase in BCP decreases the GDP by 0.864320 in long run. The findings followed Nguyen Van and Nguyen Thuc (2010) in Asian developing countries and Leandro et al (2017) in Cobo Verdo. Further, Sinha, Dipendra and Macri, Joseph (2001) found a negative and insignificant relationship for eight Asian developing countries. And Chien-Chiang Lee and Chun-Ping Chang (2009) and Elya et al (2018) found a positive and significant relationship for Argentina, Israel, Pakistan and Peru.

The empirical findings reveal that Capital investment as a percent of GDP (CI) and GDP is positive but not one on one basis and it is statistically insignificant at the $10 \%$ level. Nguyen Van and Nguyen Thuc (2010) found a positive and significant relationship between CI and GDP in Asian developing countries. Same time Sinha, Dipendra and Macri, Joseph (2001) and Athambawa Jahfer and Tohru Inoue (2014) found a negative and insignificant relationship between CI and GDP for eight Asian countries and Sri Lanka respectively.

Table 4.5: Long Run outputs of ARDL model

\begin{tabular}{|c|r|r|r|r|}
\hline \multicolumn{5}{|c|}{ Dependent Variable = LNGDP } \\
\hline Variable & Coefficient Std. Error & t-Statistic & \multicolumn{1}{|c|}{ Prob. } \\
\hline C & 1.103733 & 2.018114 & 0.546913 & 0.5893 \\
\hline LNFDI & 0.826439 & 0.286193 & 2.887702 & $0.0079^{* * *}$ \\
\hline LNCI & 0.976811 & 0.624714 & 1.563614 & 0.1305 \\
\hline LNBCP & -0.864320 & 0.230826 & -3.744465 & $0.0010^{* * *}$ \\
\hline
\end{tabular}

The value of error correction term (ECT (-1)) -0.847782 gratified the econometric conditions of being negative, between $0-1$ and significant and this value is significant at 1\%. This indicates that lngdp, lnfdi, lnci and lnbcp are cointegrated and the speed of adjustment of the external shock approximately 85 percent per year after 
disequilibrium and towards achieving equilibrium. In the short run FDI, CI and BCP have a significant and positive relationship between GDP and the value of the coefficient shows a 1.102914 percent increase in FDI is understood from one percent growth in GDP.

Table 4.6: Short Run outputs of ARDL model

\begin{tabular}{|c|c|c|c|}
\hline Variable & Coefficient & Std. Error t-Statistic & Prob. \\
\hline $\mathrm{C}$ & 0.026755 & \begin{tabular}{|l|l|}
0.065762 & 0.406847 \\
\end{tabular} & 0.6879 \\
\hline D (LNGDP (-1)) & -0.161487 & $0.128418-1.257517$ & 0.2212 \\
\hline $\mathrm{D}(\mathrm{LNFDI})$ & -0.064133 & $0.208599-0.307447$ & 0.7613 \\
\hline D (LNFDI $(-1))$ & 0.177757 & 0.1681361 .057221 & 0.3014 \\
\hline D (LNFDI $(-2))$ & -0.310984 & $0.202551-1.535337$ & 0.1383 \\
\hline D (LNFDI $(-3))$ & 1.102914 & \begin{tabular}{|l|l|}
0.1956885 .636095 \\
\end{tabular} & $0.0000^{* * *}$ \\
\hline $\mathrm{D}(\mathrm{LNCI})$ & 2.730055 & \begin{tabular}{|l|l|}
0.779118 & 3.504032 \\
\end{tabular} & $0.0019^{* * *}$ \\
\hline D (LNCI $(-1))$ & -0.759693 & $0.925344-0.820985$ & 0.4201 \\
\hline D(LNBCP) & -0.998567 & $0.302120-3.305204$ & $0.0031^{* * *}$ \\
\hline $\mathrm{D}(\operatorname{LNBCP}(-1))$ & 1.038493 & \begin{tabular}{|l|l|}
0.296962 & 3.497054 \\
\end{tabular} & $0.0019^{* * *}$ \\
\hline $\mathrm{D}(\operatorname{LNBCP}(-2))$ & -0.468333 & $0.341843-1.370023$ & 0.1839 \\
\hline $\mathrm{D}(\operatorname{LNBCP}(-3))$ & -0.835571 & $0.366180-2.281856$ & $0.0321^{* *}$ \\
\hline ECT $(-1)$ & -0.847782 & $0.219663-3.859460$ & $0.0008^{* * *}$ \\
\hline \multicolumn{2}{|c|}{ R-squared $\quad 0.889553$} & & \\
\hline \multicolumn{2}{|c|}{ Akaike info criterion 1.188893} & & \\
\hline \multicolumn{2}{|c|}{ Durbin-Watson stat $\quad 1.704503$} & & \\
\hline
\end{tabular}

Table 4.7: Diagnostic Test

\begin{tabular}{|c|c|}
\hline Test Statistics & F Statistic \\
\hline Serial Correlation* & $1.345876(0.2819)$ \\
\hline Heteroskedasticity** & $0.766552(0.6769)$ \\
\hline Normality*** & $1.420028(0.491637)$ \\
\hline
\end{tabular}

Breusch-Godfrey Serial Correlation LM Test*

Heteroskedasticity Test: Breusch-Pagan-Godfrey**

Jarque - Bera Test ***

The above table 4.7 represents the diagnostics output of the present study and shows the higher probability value at the $5 \%$ level. It proposes that the model has not an econometric problem.

\subsection{STABILITY TEST}

The final step was carried out to check the stability of the long run parameters together with the short run movements of the equations proposed by Pesaran and Pesaran (1997).

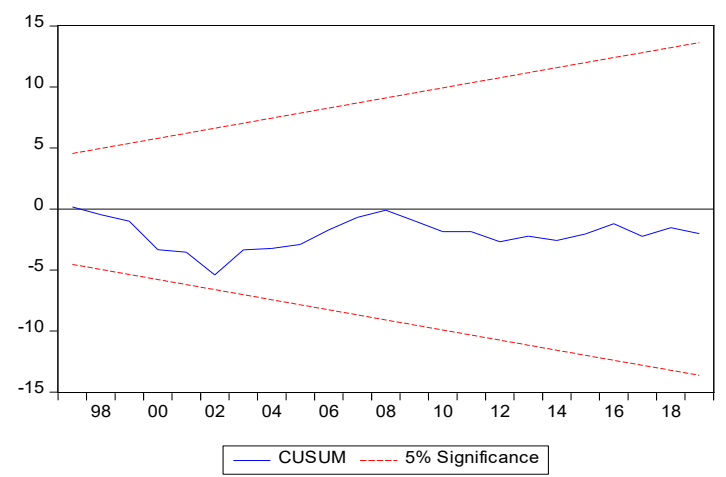

Figure:1 
S. Maheswaranathan, and K. M. N. Jeewanthi.

Based on the equation Figure 1 design the CUSUM statistics. From the above figure, 1 plot of CUSUM places between the critical value of $5 \%$ bounds which permits stability of the variables also the long-run relationships exist among variables.

\section{SUMMARAY AND CONCLUSION}

The primary objective of this study is to examine the relationship between foreign direct investment, financial development and economic growth in Sri Lanka for the period of 1980- 2019 by applying ARDL bound test and ECM, also applied the CUSUM test to test the stability of the variables. The unit root test shows that the variables are mixed of I (0) and I (1) and allowed the ARDL model. The cointegration test confirmed the long run relationship between the variables which indicates in the long run all the variables move together. Further, the CUSUM test suggests that the variables have a long-run relationship and illustrate the stability of the coefficient between the variables.

\section{SOURCES OF FUNDING}

This research received no specific grant from any funding agency in the public, commercial, or not-for-profit sectors.

\section{CONFLICT OF INTEREST}

The author have declared that no competing interests exist.

\section{ACKNOWLEDGMENT}

None.

\section{REFERENCES}

[1] Abdalla Sirag, Samira SidAhmed, Hamisu Sadi Ali. "Financial development, FDI and economic growth: evidence from Sudan." International Journal of Social (Received 25 October 2017, revised 6 March 2018, Accepted 26 March 2018) 45, no.08 (2018): 1240-1246.

[2] Aghion P., P Howitt, D. Mayer-Foulkes. "The Effect of Financial Development on Convergence: Theory and Evidence." The Quarterly Journal of Economics, 2005: 173-222

[3] Alfaro, L., C. Areendam, S. Kalemli-Ozcan, and S. Sayek. "FDI and economic growth: The role of the financial markets." Journal of International Economics, 2004: 89-112.

[4] Asghar N, Z Husn sain. "Financial Development, Trade, Openness and Economic Growth In Developing Countries Recent Evidence from Panel Data." Pakistan Economic and Social Review, 2014: 100 - 103.

[5] Athambawa J, and Tohru I. "Financial development, foreign direct investment and economic growth in Sri Lanka." Edited by Copyright (C) 2014 Inderscience Enterprises Ltd. International Journal Economic Policy in Emerging Economies Vol. 7, No. 1 (2014).

[6] Belloumi, M. "The relationship between Trade, FDI and Economic growth in Tunisia: An application of autoregressive distributed lag model." 2002: 2-6.

[7] Chee-Keong Choong and Kian-Ping Lim; Foreign direct investment, financial development, and economic growth: the case of Malaysia ISSN 1752-0843 print/ISSN 1752-0851 online

[8] _ 2009 Taylor \& Francis, Macroeconomics and Finance in Emerging Market Economies Vol. 2, No. 1, March 2009, 13-30 DOI: 10.1080/17520840902726227; http://www.informaworld.com

[9] Chien L C, And P Chun C. "Fdi, Financial Development, And Economic Growth: International Evidence." Journal f Applied Economics (Submitted April 2008; Accepted February 2009) Xii (November 2009): 249-271.

[10] Choong, C-K, z. yusop, and S-O Soo. "Foreign direct investment, economic growth, and financial sector development." ASEAN Economic Bulletin, 2004: 278-289. 
[11] Deidda L, B Fattouh. "Banks, Financial markets and growth." Journal of financial intermediation, Volume 17 Issue 1 January 2008: 6-36.

[12] Deidda L, B Fattouh. "Non-linearity between Finance and Growth." Economics Letters, 2002: 339-345.

[13] Eggoh C Jude, "Financial Development and Growth: A Panel Smooth Regression Approach." Journal of Economic Development, 2010: 15 - 17.

[14] Elya A Bahri, Abu S M Nor, et al... "Foreign Direct Investment, Financial Development and Economic Growth: A Panel Data Analysis." Jurnal Pengurusan 51 (2018): 11-12.

[15] Hermes N, and Lensink R. "FDI, financial development and economic growth." Journal of Development Studies Vol. 38 (February 2003): 142-163.

[16] Leandro D R V D, Y Kedong and L Xueme. "The Relationship between FDI, Economic Growth and Financial Development in Cabo Verde." International Journal of Economics and Finance; Vol. 9, No. 5; 2017; SSN 1916971X, E-ISSN 1916-9728 Published by Canadian Center of Science and Education Received: March 21, 2017; Accepted: April 20, 2017; Online Published: April 25, 2017

[17] Levine, R 1997, „Financial development and economic growth: Views and agenda“, Journal of Economic Literature, Vol.35, pp. 688-726

[18] Nguyen Van Phuc, Nguyen Thuc Duy Anh. "Foreign Direct Investment, Financial Development and Economic Growth in Asian Developing Countries." 2010: 6-14.

[19] Omran M., and Bolbol A. "Foreign direct investment, financial development, and economic growth: evidence from the Arab countries." Review of Middle East Economics and Finance 1, no. 3 (December 2003): 238-247.

[20] Sghaier, Imen Mohamed, and Abida. "Foreign Direct Investment, Financial Development and Economic Growth: Empirical Evidence from North African Countries." Journal of International and Global Economic Studies (6)1 (June 2013): 4-7.

[21] Sinha Dipendra and Macri Joseph (2001) "Development and Economic Growth: The Case of Eight Asian Countries" Economia Internazionale/ International Economics, Camera di Commercio Industria Artigianato Agricoltura di Genova, vol. 54(2), pages 219-234.

[22] "Economics and Social Statistics of Sri Lanka." 2020.

"World Bank Report 2020" 